\title{
New Rules for the Calculation of the Moment and the Moment of Inertia of a Plane Area about its Middle Ordinate.
}

\author{
By Seinen Yokota, Member.
}

\begin{abstract}
Simple and accurate rules similar to that of Tchebycheff. A numerical example is given for a sine curve and the result compared with those by Gauss', Tchebycheff's, Simpson's and Trapezoidal rules.
\end{abstract}

The method about to be explained is, as formerly suggested by the author, the extension of the Tchebycheff's. (Kōgaku Kwaishi No. 242. 1902.)

The Tchebycheff's rule, though very convenient to find a plane area, involves the multiplication of each ordinate with the leverage when its moment and the moment of inertia about the middle ordinate are to be calculated. The process is rather troublesome when several areas and consequently a large number of ordinates are to be dealt with, as in the case of the shipbuilding calculation.

According to the following method, the moment and the moment of inertia are given directly by the simple sum of the ordinates multiplied by a constant, the troublesome multiplication of each ordinate with the corresponding leverage being altogether eliminated, and, in addition to this remarkable simplification, the accuracy of the result is increased when compared with some of the existing rules.

Let

$$
y=c_{0}+c_{1} x+c_{2} x^{2}+\ldots \ldots+c_{n} x^{n}, \ldots \ldots \ldots \ldots \ldots \ldots \text { (1) }
$$

where $c_{v}, c_{1}, c_{2}, \ldots, c_{n}$ are constants and $n$ a positive integer, be the equation of the boundary curve. Then, if $l$ denotes the half-length of the base, the moment $M$ of the area about the middle ordinate is

$$
M=\int_{-l}^{l} y x d x
$$

Again let 


$$
\begin{aligned}
& \text { 恝 }
\end{aligned}
$$

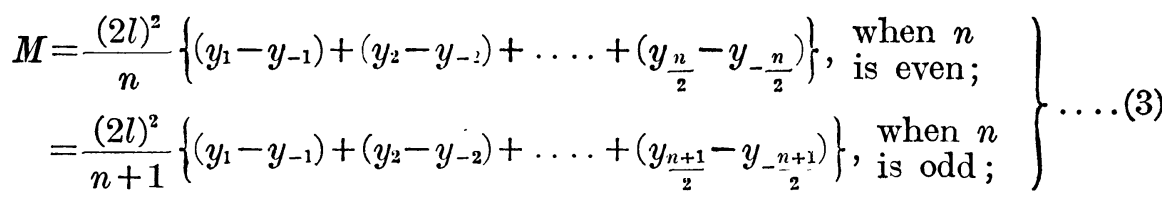

where $y_{1}, y_{-1}, y_{2}, y_{-2}, \ldots, y_{\frac{n}{2}}, y_{-\frac{n}{2}}, y_{\frac{n+1}{2}}, y_{-\frac{n+1}{2}}$ are the values of $y$ corresponding to $x_{1},-x_{1}, x_{2},-x_{2}, \ldots, x_{\frac{n}{2}},-x_{\frac{n}{2}}, x_{\frac{n+1}{2}},-x_{\frac{n+1}{2}}$, which are so determined that the expressions (2) and (3) might be equal to one another. Equating the coefficients of $c_{1}, c^{3}$, $\ldots, c_{n-1}$ or $c_{n}$ in (2) and (3) according as $n$ is even or odd, we get a system of the following equations :

$$
\left.\begin{array}{c}
a_{1}+a_{2}+\ldots+a_{\frac{n}{2}}=n /(4.3), \\
a_{1}^{3}+a_{2}^{3}+\ldots \ldots+a_{\frac{n}{2}}^{3}=n /(4.5), \\
\ldots \ldots \ldots \ldots \ldots \ldots+a_{\frac{n}{2}}=n /(4 . \overline{n+1}) ; \\
a_{1}^{n-1}+a_{2}+\ldots \ldots+1
\end{array}\right\}
$$

where $a_{1}=x_{1} / l, a_{2}=x_{2} / l, \ldots, a_{\frac{n}{2}}=x_{\frac{n}{2}} / l$, and the integer $n$ now denotes the even numbers only, since the case when $n$ is odd leads to the equations of the same form: as (4).

By means of the Newton's formulae giving the relations between the coefficients of an algebraic equation and the sums of the integral powers of its roots, the equations (4). were converted into a single equation of the degree $n / 2$ and its roots calculated by the Horner's method.

The deduction of the rule for the moment of inertia is quite similar and would require no further explanations.

The rules with the values of the abscissae ar' given below.

$$
\begin{aligned}
& \text { Moment }=\frac{(2 l)^{2}}{n}\left\{y_{1}+y_{2}+\ldots+y_{\frac{2}{2}}-\left(y_{-1}+y_{-2}+\ldots+y_{-\frac{n}{2}}\right)\right\} \\
& n=\frac{x_{1}}{l} \quad \frac{x_{2}}{l} \quad \frac{x_{3}}{l} \quad \frac{x_{4}}{l} \quad \frac{x_{5}}{l} \\
& 4:-0.2701 \quad 0.6034
\end{aligned}
$$

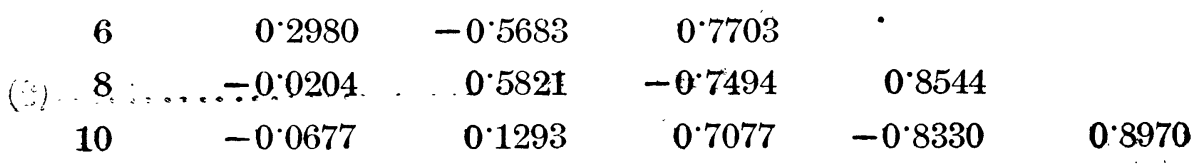


Moment of Inertia $=C\left(y_{1}+y_{2}+\ldots+y_{\frac{n}{2}}+y_{-1}+y_{-2}+\ldots+y_{-\frac{n}{2}}\right)$.

$\begin{array}{ccccc}n & C & x_{1} / l & x_{2} / l & x_{3} / l \\ 2 & l^{3} / 3 & 0.7746 & & \\ 4 & l^{3} / 6 & 0.5815 & 0.9284 & \\ 6 & l^{3} / 9 & 0.5030 & 0.8133 & 0.9410\end{array}$

(For $n=8$ and higher values, the abscissae become imaginaries.)

As an example, the moment and the moment of inertia of the area bounded by the curve of sine between 0 and $\frac{\pi}{2}$ are calculated by several rules and the results compared with the exact values.

\section{Moment}

Exact value 0.2146018

My rule

Gauss'

0.214611 ( 8 ordinates) $0.214602(4 \quad, \quad)$

Tchebycheff's $0 \cdot 214604(9 \quad, \quad)$

Simpson's $0.214589(11 \quad$, )

Trapezoidal $0.218276(11 \quad, \quad)$
- Moment of inertia $0 \cdot 1876466$

0.187648 ( 6 ordinates)

$0.187648(4 \quad, \quad)$

$0.187651(9,, \quad)$

$0.187612(11 \quad,, \quad)$

$0 \cdot 189617(11 \quad, \quad)$

Judging from this and several other examples, the present rules appear to give generally more accurate results than the Simpson's or the Trapezoidal rule, while the process of calculation is surprisingly simple if compared with the Gauss' and the Tchebycheff's.

\section{討 論}

○會長（今岡純一郎君）御質問なり、御討論なりありませぬか、・......橫旪博士も、前回御講 演の末廣博士と共に本協會に於ける權威西る學者として、常に協會の爲に御研究を御潑表下され、今 また新らしき計算式を御發表に相成りました。是に依つて吾々造船に從事する者は、多大の利便を得 るとと〉思ひます。將來皆さんが此「ルール」を御使ひになつて、橫田君の御勸めを實際に應用せら れんととを望む炏第ですります。此御莈表に對し拍手を以て御禮を申上げたいと思ひます。 